\title{
PRESENTING THE CLIR DATABASE MODULE FOR PROCESSING ROMAN STAMPED TILES AND CERAMIC BUILDING MATERIALS (CBM) ${ }^{1}$
}

\section{GERGố IstVÁn FARKAs ${ }^{2}$}

Hungarian Archaeology Vol. 10 (2021), Issue 4, pp. 18-26. https://doi.org/10.36338/ha.2021.4.2

The subject of the following article is a long time research topic of Roman frontiers studies in Pannonia. The analysis of tile stamps and in recent decades, more inclusive analysis of Ceramic Building Materials (CBM) has provided information for a wide range of limes-related research. From the more classical disciplines of auxiliary dislocation and the chronology of building phases, to more Modern approaches such as landscape archaeology and spolia studies, CBM finds are an extensive and multifaceted find group, providing both natural scientific data and epigraphic/iconographic data. The sheer quantity of Roman CBM necessitates the use of databases and in collaboration with the novel CLIR database, the following article presents a viable solution for recording and assessing these finds.

Keywords: CBM, Quantitative Latin epigraphy, Highlight-Reflectance Transformation Imaging (HRTI), Archaeological database

\section{INTRODUCTION}

Roman tiles were collected by antiquarians since the Renaissance, as attested by various contemporary manuscripts, with emphasis on stamped, incised and intact specimen. Most epigraphical collections included marked tiles (and other instrumenta inscripta for that matter e.g. Torma, 1883), yet unmarked tiles, comprising the vast majority of Ceramic Building Materials (CBM) are understandably absent from these collections. ${ }^{3}$ In Hungary, markings on tiles have been documented as early as the $19^{\text {th }}$ century both systematically (e.g. Pósta 1897; Wosinsky 1896), and sporadically (e.g. Grosschmied 1836; RÓMER 1886;).

The study of CBM as raw materials, architectural features and industrial products is by no means a novity, and the methodology for recording extensive amounts of tiles has been constantly refined and perfected since the 1970s in English literature (McWHIRR 1978). Relying on simple observations confirmed by material analysis on randomly selected specimen, these studies proposed and eventually answered multiple questions concerning the transportation of tiles, personnel and stamps, distinguished tiles manufactured in different workshops and mapped some of the commerce routes. Studies of similar scopes in Hungary were first penned in the early 2000s, and the dissertations of Lóránd Olivér Kovács (KovÁcs 2003; 2005), Zoltán Havas (Havas 2005; 2019) constitute prominent milestones in the research of Pannonian CBM. These works adopted the internationally formed scientific framework and established a Hungarian terminology, enabling the evaluation of Hungarian CBM finds in the future.

At the moment, there are a handful of sites and edifices, which have their CBM thoroughly documented, including buildings discovered at Szőny-Vásártér (BORHY \& SzÁMADó 1999; for an overview cf. Borhy 2014), Tác-Gorsium/Herculia (KovÁcs 2005) and the governor's palace on the Hajógyári Island

\footnotetext{
This article was presented on the $26^{\text {th }}$ Virtual Annual Conference of the European Association of Archaeologists on $29^{\text {th }}$ August 2020 titled "Building Empires - New Research on CBM and Stamped Tiles on Roman Frontiers - Introducing the CLIR Research Center and Limes Database".

Völgységi Museum. E-mail: farkas.istvan.gergo@gmail.com

3 In terms of Pannonian tiles, most important corpora are the Corpus Inscriptionum Latinarum (CIL) and the Römische Inschriften Ungarns (RIU), alongside several extensive regional or thematic collections and online databases such as the Epigraphic Database Heidelberg (EDH at https://edh-www.adw.uni-heidelberg.de/home), Ubi Erat Lupa (http://lupa.at/) and various other registers.
} 
Gergö István Farkas • Presenting the CLIR Database Module for Processing Roman Stamped Tiles and Ceramic...

in Budapest/Aquincum (Havas 2019). Nonetheless, the tendency for recording CBM finds in great detail is present and every year, the material available for analysis is increasing substantially. Recent decades saw a prominent rise in the number of known Roman CBM finds in Pannonia, as they are becoming more widely recognized sources of information: at the moment the most extensive collection belongs to the Aquincum Museum in Budapest, which holds approximately 10.000 tiles (Havas 2019, 72, fn. 131), followed by the Stadtmuseum Wien with approx. 4.000 tiles from Vindobona (tegula.org), ${ }^{4}$ and several hundred tiles in regional museums at Komárom, Székesfehérvár, Dunaújváros and other along the limes and in the hinterland.

\section{METHODOLOGY OF RECORDING DATA}

The means for recording large quantities of CBM efficiently and in sufficient detail has already been established in the 1970s. The methodology has been tried and tested, consisting of considerable academic literature (McWhirr, 1979; 309-401; McComish s. a.; Desbat 1981, 55-81; Ferdière 2012), from extensive field documentation and sampling (McСомIsH 2015), to functional classification (Havas 2019, 72-73), to production methods (BETTS 1985, 158-162), to the distinction of different workshops (HAVAs 2019, 75) to the classification of drawn designs (WARRY 2006, 91; BRODRIBB 1989, 102) and the administrative aspects of the brick industry (AUBERT 2005, 53-59). Earlier research raised multiple questions to which CBM research can provide answer. As a result, the raw materials used for tile production (CLEMENT 2016, 146-148), manufacturing processes and tools (used for shaping, firing and surface treatment), as well as the typology of tiles themselves and most of the markings used upon them are largely agreed upon by professionals. The necessary translations of academic terminology have been made (e.g. for German terminology CzYsz 2001, 146-151; for Hungarian terminology Kovács 2005 and Havas 2019).

Table 1. Primary data recorded in the Finds module of the CLIR database concerning CBM material. Fields marked with asterix (*) should be recorded on the field

\begin{tabular}{|c|c|c|}
\hline Nr. & Data type & Data type in database \\
\hline 1 & $\begin{array}{l}\text { Identification } \\
\text { Find ID*, Inventory Nr., Acquisition Nr., IDs from other } \\
\text { databases or records }\end{array}$ & Sets of individual IDs, links to online collections (URL) \\
\hline 2 & $\begin{array}{l}\text { Localization of findspot (down to archaeological feature } \\
\text { level, wherever possible)* }\end{array}$ & $\begin{array}{l}\text { Polygons, polylines and centroids for visualising } \\
\text { the location and relations between sites, features and finds. }\end{array}$ \\
\hline 3 & Form or shape (based on existing typologies) & Multiple choice values from taxonomy term trees \\
\hline 4 & $\begin{array}{l}\text { Dimensions (different tile shapes necessitate a complex } \\
\text { set of measurements, with an optimal precision of } \\
\sim 0.5 \mathrm{~cm} \text { and } 1^{\circ} \text { ), }\end{array}$ & $\begin{array}{l}\text { Sets of different measurements based on site / feature / } \\
\text { finds node type }\end{array}$ \\
\hline 5 & $\begin{array}{l}\text { Markings (tally marks, decorations or other marks made } \\
\text { with finger or a tool) }\end{array}$ & Multiple choice values from taxonomy term trees \\
\hline 6 & $\begin{array}{l}\text { Inscriptions (engraved, painted, stamped or incised } \\
\text { inscriptions) }\end{array}$ & $\begin{array}{l}\text { Transcription and interpretation (according to the Leiden } \\
\text { conventions) recorded as text, attributes (function, } \\
\text { engraving method, decorations etc.) recorded multiple } \\
\text { choice values from taxonomy term trees, dimensions } \\
\text { recorded as sets of individual values }\end{array}$ \\
\hline 7 & $\begin{array}{l}\text { Stamps (all data concerning tilestamps, e.g. dimensions, } \\
\text { text, type) }\end{array}$ & $\begin{array}{l}\text { Transcription and interpretation (according to the Leiden } \\
\text { conventions) recorded as text, attributes (function, } \\
\text { engraving method, decorations etc.) recorded multiple } \\
\text { choice values from taxonomy term trees, dimensions } \\
\text { recorded as sets of individual values }\end{array}$ \\
\hline 8 & $\begin{array}{l}\text { Animal imprints (exact definitions necessitate } \\
\text { archaeozoological confirmation) }\end{array}$ & Textual description \\
\hline
\end{tabular}

${ }^{4}$ https://www.interactive-art.at/crazy-eye/WebGIS/Gestempelte-Ziegel-aus-Vindobona/\#15/48.2022/16.3731. 

Gergö István Farkas • Presenting the CLIR Database Module for Processing Roman Stamped Tiles and Ceramic...

\begin{tabular}{|r|l|l|}
\hline Nr. & Data type & Data type in database \\
\hline 9 & Colour (based on Pantone or equivalent colour charts) & Textual description / calibrated colour profiling \\
\hline 10 & $\begin{array}{l}\text { Position (the position of the fragment compared to the } \\
\text { intact tile) }\end{array}$ & Textual description \\
\hline 11 & $\begin{array}{l}\text { Processing (any technical feature relevant to } \\
\text { manufacture) }\end{array}$ & $\begin{array}{l}\text { Textual description and multiple choice values from } \\
\text { taxonomy term trees }\end{array}$ \\
\hline 12 & Fabric (raw material, binding agents and impurities) & $\begin{array}{l}\text { Textual description and multiple choice values from } \\
\text { taxonomy term trees }\end{array}$ \\
\hline
\end{tabular}

Table 2. Secondary data recorded concerning CBM finds (subsequent supplements to the data recorded on the field and during primary assessment).

\begin{tabular}{|r|l|l|}
\hline Nr. & Data type & Data type in database \\
\hline 1 & $\begin{array}{l}\text { Circumstances of custody (place of custody, date of } \\
\text { recording find in inventory, revisions, method and details } \\
\text { of acquisition, recorder's name etc.) }\end{array}$ & $\begin{array}{l}\text { Textual description and multiple choice values from } \\
\text { taxonomy term trees; personnel, institutions and research } \\
\text { activities recorded as separate auxiliary nodes }\end{array}$ \\
\hline 2 & $\begin{array}{l}\text { Bibliography or literature concerning individual tile or } \\
\text { type }\end{array}$ & Zotero entries \\
\hline 3 & Manufacturing techniques & Multiple choice values from taxonomy term trees \\
\hline 4 & State of preservation & $\begin{array}{l}\text { Multiple choice values from taxonomy term trees } \\
\text { Commentary or description (present state, storage } \\
\text { taxonomy term trees }\end{array}$ \\
\hline
\end{tabular}

These are the general foundations for CBM-related research, which need to be complemented with some local characteristics, most of which are related to ancient aspects of the material, such as slight regional variations in Roman standards, differing climate conditions and varying regional architectural techniques and practices. Some regional characteristics, however, are the results of Modern events, including excavation circumstances, documentation practices and storage conditions. Especially in Eastern and Southern Europe, the devastations of the World Wars were worsened by subsequent occupation, resulting in the destruction of numerous archaeological artifacts and documentation, a great loss of data, that is still hindering the evaluation of the find material.

\section{THE METHODOLOGY OF DIGITAL DOCUMENTATION}

In the course of the past centuries, simple drawings were generally used for recording the surface of marked tiles, pencil shading and lottinoplastie were less common. Nowadays, the general approach includes either colour proofed photo documentation or photos taken with grazing light, as both are fast, reliable and storage space friendly solutions. Recording select features on the surface of tiles and CBM finds, or recording entire objects as 3D models is possible using photogrammetry and laser scanning, although both demand considerable time and hardware.

Highlight Reflectance Transformation Imaging (H-RTI or Multi Light Imaging) provides an efficient digital documentation alternative. The method consists of taking a set of photos in a dark room with a fixed objective lens set perpendicular to the subject surface while illuminating this surface with a pointed light of uniform intensity (set to a fixed distance from the surface) and varying directions. This H-RTI process yields a 2.5 dimension model, which can simulate the illumination of the documented surface or apply algorithms to highlight features projecting from or sunken into the surface. Thus, this method is most useful in documenting flat objects and worn surfaces and enhancing their interpretation (Fig. 1).

Creating a H-RTI model necessitates the same tools as object photography, most DSLR/MILC camera bodies and base objective lenses are capable of creating photos of adequate quality. The software used for constructing the H-RTI model is open source ${ }^{5}$ and has modest hardware requirements (most present

\footnotetext{
http://culturalheritageimaging.org/
} 
Gergö István Farkas • Presenting the CLIR Database Module for Processing Roman Stamped Tiles and Ceramic...

day multi-core processors enable seamless work). Shooting photos necessitates 1-2 minutes (a model of sufficient detail can be created from 40-50 photographs) and the models are generated in 5-10 minutes.

Tom Malzbender and his colleagues created the H-RTI process in 2001 (Malzbender, Gelb \& Wolters 2001), in the last two decades the method gained widespread academic recognition. Due to constant technological progress and the extensive quantity and variety of finds processed with this method, H-RTI has been thoroughly refined with numerous articles and technical documentation available to tailor the process to any find type. ${ }^{6}$

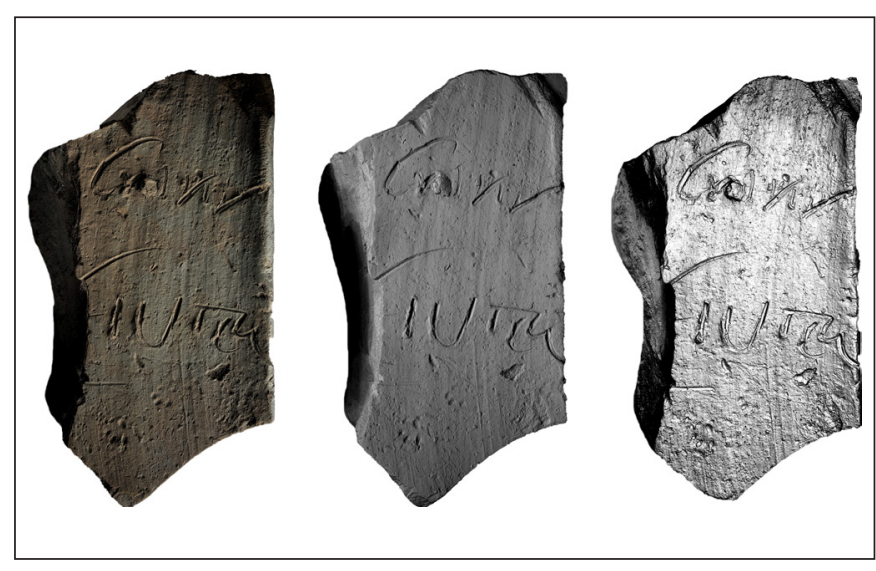

Fig. 1. Images taken from the 2.5 dimension H-RTI model of an incised Roman tile using different lighting (Image by Gergö Farkas)

\section{THE CBM MODULE OF THE CLIR DATABASE}

CBM research is not independent from the inherent characteristics of the find material: the sheer quantity of the material is fascinating (Roman tiles from York amount to a not inconsiderable 8.11 tonnes, McComisH s. a., 1, 66), yet this material of incredible magnitude can be described fairly well with a rather clear typology. Nonetheless the circumstances of discovery in case of individual CBM finds is largely varied, many of them were collected during well documented archaeological excavations, while the findspots and provenience of others is completely unknown. Because of these characteristics, it is fairly clear, that CBM finds should be recorded and assessed through an online archaeological database. The online nature of the database is crucial for enabling widespread international collaboration, otherwise, the material would be broken down into a set of mostly matching regional collections.

Such goal was kept in mind while developing the Corpus Limitum Imperii Romani (CLIR) database, which encompasses archaeological sites and features on the Frontiers of the Roman Empire. It is research initiative with a history spanning five decades (VISY 2015, 929-929; FARKAS 2019, 159-165).

The novity of the CLIR database lies in its expressed aim to record archaeological sites and features in their original complexity, yet in a manageable and overseeable manner. The first of the three major pitfalls that needed avoiding, was oversimplification: if a database cannot mirror the unavoidable ambiguities of localization, interpretation or interrelation, then it is insufficient for scientific analysis and at best can only be used as a register for future research. The second extremity to avoid was recording real life archaeological entities in theoretically correct, yet unadaptable, rigid datasets, which in long term would prohibit adding new data to the existing system and thus limit its usability. The third peril to avoid was not having the database developed by professional standards - database development is a veritable discipline of its own, with standards and good-practices, yet one can come across a wide range of archaeology-themed databases, that were created without any of the database schemata and related integration requirements.

The CLIR database at https://clir.hu was developed with these concerns in mind. The structure and functionality of this object-oriented database is the subject of a separate article (FARKAS 2021, 23-34). In short, it is a database consisting of sets of different nodes, which can be related to each other in unlimited manner and each node may be assigned attributes organized in taxonomy term trees (hierarchies of terms). The most important nodes are Sites, Site components, Component parts and Finds, which cover the entire spectrum of an archaeological site from the topmost Site level, which can be broken down into separate entities (e.g. individual edifices, structures etc.), which can be further broken down into individual archaeological features (e.g. individual pits, fills, layers etc.). The relations between these node types is one-way

6 Presenting merely an overview of relevant literature would exceed the boundaries of this study, thus only a selection of related works and guidelines are quoted here: https://www.loc.gov/preservation/digital/formats/fdd/fdd000486.shtml 
Gergö István Farkas • Presenting the CLIR Database Module for Processing Roman Stamped Tiles and Ceramic...

open, meaning that a Site can be child of only another Site, it cannot be the child of another node type, yet the number of parent-child relations between Sites is otherwise unlimited (Fig. 2).

Note, that different Sites can possess different numbers of children, e.g. Site "A" has twelve, Site "B" has three and Site "C" has four. The number of children and the number of parent-child relations is unlimited. Individual nodes may be grouped together in multiple ways. It is possible to group together certain nodes from a single parent as a Component group, e.g. wall sections, gates and towers in a single auxiliary fort may form a group titled "defences". All types of nodes spanning multiple Sites, may be joined together in Site complexes, such as Saxon shore forts, or a limes section. Individual nodes can also be connected through relations, thus hypothetical relations or other similarities are also recordable in the database.

This system is flexible enough to handle archaeological sites with varying complexities. For example a Roman watchtower is a rather simple structure (see item "B1" on Figure 1), consisting of a main tower

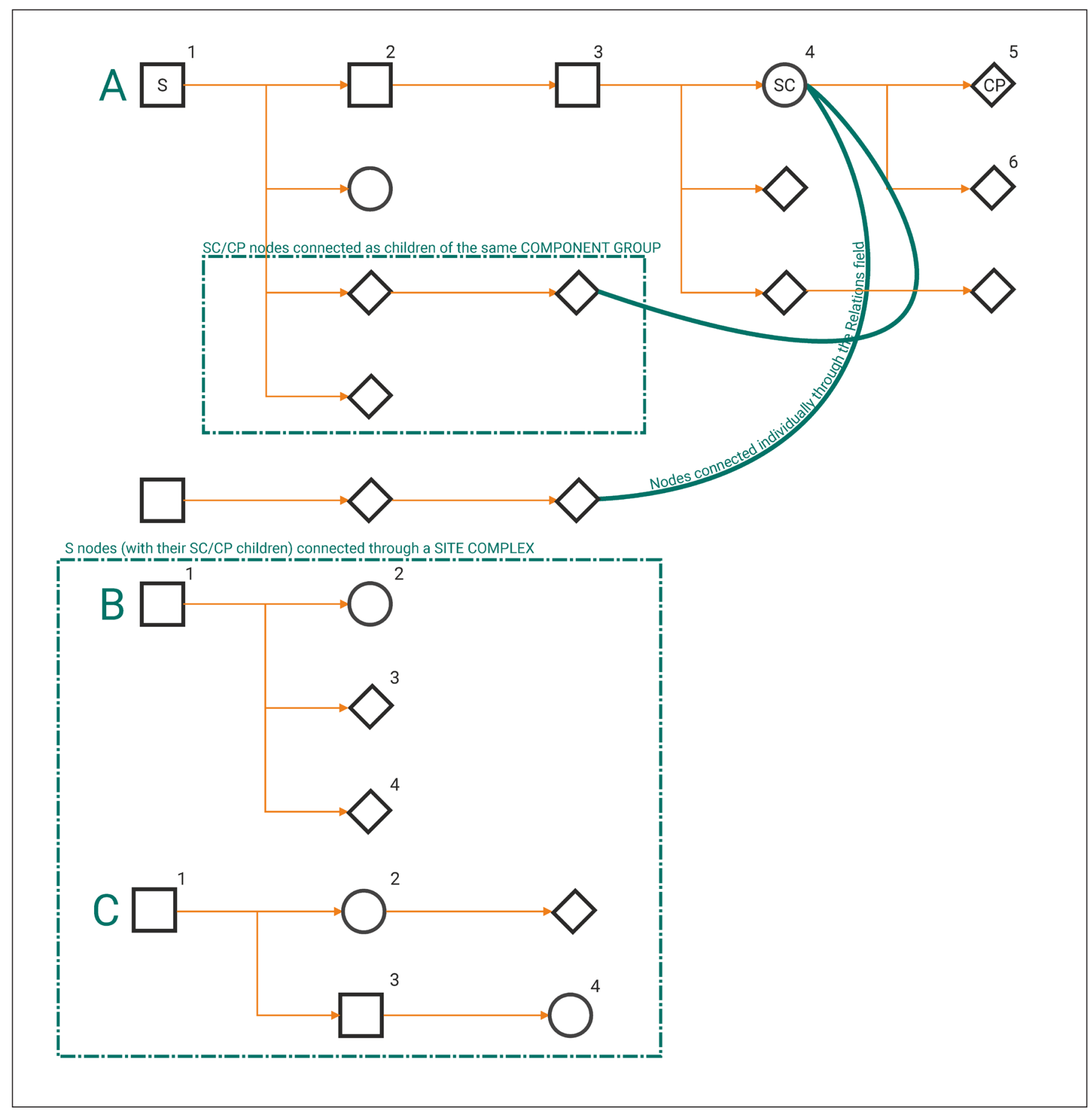

Fig. 2. The modular structure of the CLIR database (Image by Gergö Farkas) 
Gergö István Farkas • Presenting the CLIR Database Module for Processing Roman Stamped Tiles and Ceramic...

building (“B2”), encircled by a rampart ("B3") and a ditch ("B4"). Pompeii (“A1”) is quite the opposite, yet despite its vast area, it is possible to break it down into a complex structure of districts ("A2"), blocks ("A3"), edifices ("A4"), rooms ("A5") and walls ("A6"). Special site features, such as a fort annex ("C3") can be related to the fort it was built to ("C2") as a child Site. An edifice in the fort annex ("C4") is thus related to the original fort. The nature of this relation is visible in the database hierarchy, and it can be further elaborated in the textual description.

The keyword concerning the recording of data in the CLIR database is "possible". Although the CLIR database enables recording sites in utmost complexity, contributors are by no means compelled to having to upload all data. Although it is possible, it is not obligatory, thus not placing an unreasonable burden on those without the necessary time and resources to complete such a gargantuan task.

For the intents of this article, the most important node type of the database is the one dealing with finds. The Finds node type can be related to any other node type listed above, thus the database handles both exact locations and uncertain provenience. Other nodes play supplementary role in the database, these include Personnel, Institutions and Research activities.

All nodes have a wide range of fields to record their identification, localization, descriptions and so on, which contain all necessary data listed in the chapter above, based on accepted research methodologies. Another important feature of the database is, that all nodes can be attributed with unlimited number of terms from sets of hierarchal taxonomies, describing their different aspects in a way that enables complex queries and extensive comparisons (Fig. 3)

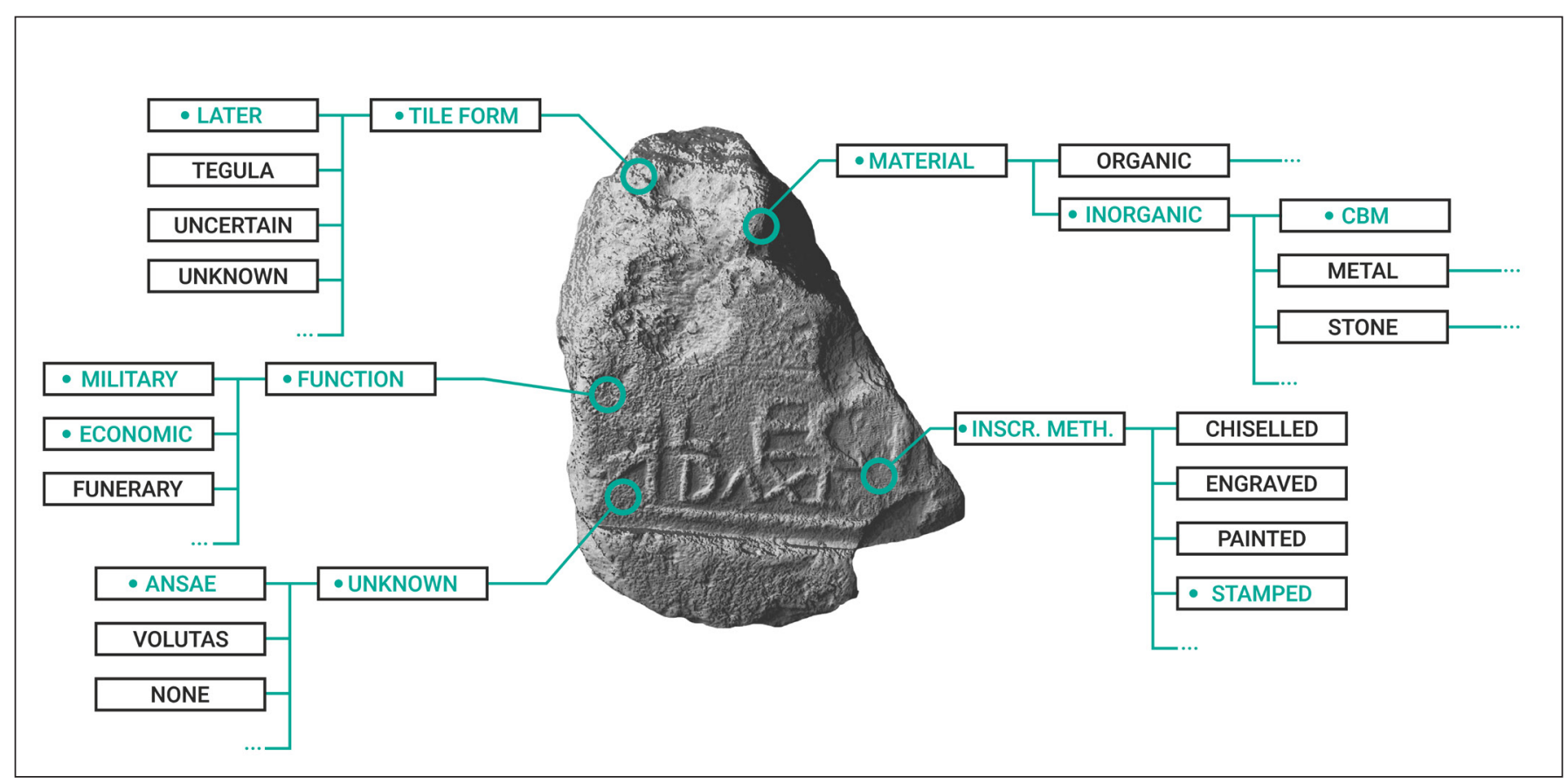

Fig. 3. Node attributes in taxonomy term trees demonstrated on the H-RTI image of a Roman tile (Both images by Gergö Farkas)

\section{FUTURE PLANS}

The goal of CLIR database and its CBM module is to provide an adaptable and intuitive solution for recording vast quantities of archaeological data, in collaboration with existing institutions, frameworks and projects. The module is scheduled for publication in 2023, development and testing is still underway at the time when this article was submitted (12.11.2021). The first datasets scheduled for upload are the Roman CBM material of counties Baranya and Tolna in Hungary, which is important as these limes sections are still an academic grey area concerning. 
Gergö István Farkas • Presenting the CLIR Database Module for Processing Roman Stamped Tiles and Ceramic...

LINKS AND ONLINE CONTENT

The CLIR database: https://clir.hu

Blog site of the CLIR Research Center: https://www.clir-research.hu/

A description of the CLIR programme (in Hungarian): https://integralvision.hu/hu/munkak/clir

\section{LITERATURE}

Aubert, J.-J. (2005). L'estampillage des briques et des tuiles: une explication juridique sur une approche globale. In: C. Bruun (ed.), Interpretare i bolli laterizi di Roma e della Valle del Tevere: produzione, storia economica et topografia. Atti del convegno all'École française de Rome e all'Institutum Romanum Finlandiae, Rome, 31 mars-1er avril 2000, Institutum Romanum Finlandiae (pp. 53-59). Coll. Acta Instituti Romani Finlandiae 32. Róma: Institutum Romanum Finlandiae.

Betts, I. M. (1985). A Scientific Investigation of the Brick and Tile Industry of York to the Mid-Eightteenth Century. Unpublished PhD thesis. University of Bradford.

Borhy, L. \& Számadó, E. (2001). Beszámoló a Komárom/Szőny-Vásártér 2. számú háznál 1999-2001 folyamán végzett feltárásokról. Komárom Esztergom Megyei Önkormányzat Múzeumainak Közleménye 8 (2001), 143-162.

Borhy, L. (2014). Bibliography of the excavations in Brigetio (1992-2014). Dissertationes Archaeologicae ex Instituto Archaeologico Universitatis de Rolando Eötvös nominatae 3/2 (2014), 565-580. http://dx.doi. org/10.17204/dissarch.2014.565

Brodribb, G. (1989). Roman Brick and Tile. Gloucestershire: Alan Sutton Publishing.

Clement, B. (2016). L'industrie de la brique crue dans la colonia Lugdunum (Lyon). In S. Camporeale, J. Delaine \& A. Pizzo (dir.), Arqueologia de la construccion V. Coll. Anejos de Archivo español de arqueología LXXVII (pp. 146-164). Oxford, 2016.

Czysz, W. (2001). Die spätrömische Töpferei und Ziegelei von Rohrbach im Landkreis Aichach-Friedberg - Ausgrabung des Brennofens 1 (1983). Berichte der Bayerischen Bodendenkmalpflege 41-42 (2000/2001), 129-159.

Desbat, A. (1981). L'architecture de terre à Lyon à l'époque romain. In St. Walker (dir.), Récentes recherches en archéologie gallo-romaine et paléochrétienne sur Lyon et sa région (pp. 55-81). BAR International Series 108. Oxford: Archaeopress.

Farkas, I. G. (2019). (Notes from the trial of) the CLIR database. In I. G. Farkas, R. Neményi \& M. Szabó (eds), VISY75 Artificem commendat opus. Studia in honorem Zsolt Visy (pp. 159-165). Pécs: CLIR Research Center.

Farkas, I. G. (2020). New Roman Stamped Tiles from Altinum (Kölked). In I. G. Farkas, R. Neményi \& M. Szabó (eds), The Danube Limes in Hungary: Archaeological Research Conducted in 2015-2020 (pp. 255-271). Pécs: CLIR Research Center. https://doi.org/10.15170/CLIR.2020.11

Farkas, I. G. (2021). The CLIR database at https://clir.hu. In Zs. Visy (ed.), Proceedings of the Corpus Limitum Imperii Romani (CLIR) Online Conference Held on the 14 th of May, 2021 (pp. 23-34). Pécs: Hungarian Academy of Sciences, Pécs Regional Committee. 
Gergö István Farkas • Presenting the CLIR Database Module for Processing Roman Stamped Tiles and Ceramic...

Ferdière, A. (2012). La production de terres cuites architecturales en Gaule et dans l'Occident romain, à la lumière de l'exemple de la Lyonnaise et des cités du nord-est de l'Aquitaine: un artisanat rural de caractère domanial? Revue archéeologique du Centre de la France 51 (2012), 17-187.

Grosschmied, G. (1836). Az ó-budai kis-sziget [The small island of Old Buda]. Regélö 66 [18 August 1836], 521-523.

Havas, Z. (2005). Az óbudai hajógyári-szigeti helytartói palotakomplexum kerámia épitészeti elemei [Ceramic architectural elements in the governor's palace on Hajógyári Island in Old Buda]. MA Thesis. Budapest: Eötvös Loránd Tudományegyetem, 2005.

Havas, Z. (2019). The Brick Architecture of the Governor's Palace in Aquincum. PhD disszertáció. Budapest: Eötvös Loránd Tudományegyetem, 2019.

Janek, T. (2017). On the Production and Distribution of the Ceramic Building Material in Vindobona. Studia Hercynia 2, 1 (2017), 81-96.

Kovács, L. O. (2003). Égetett agyag tetöfedő elemek a táci római kori településröl. Szakdolgozat. Budapest, Eötvös Loránd Tudományegyetem, 2003.

Kovács, L. O. (2005). Égetett agyag tetőfedő elemek a táci római kori településről [Burnt roof covering elements from the Roman settlement of Tác]. Alba Regia. A Szent István Király Múzeum Évkönyve 35 (2005), 137-242.

Lőrincz, B. (1977). Pannonische Stempelziegel I: Limes-Strecke Annamatia-Ad Statuas. Dissertationes Archaeologicae ex Instituto Archaeologico Universitatis de Rolando Eötvös nominatae 2/5. Budapest: ELTE.

Lörincz, B. (1979). Pannonische Stempelziegel II: Limes-Strecke Vetus Salina-Intercisa. Dissertationes Archaeologicae ex Instituto Archaeologico Universitatis de Rolando Eötvös nominatae 2/7. Budapest: ELTE.

Lörincz, B. (1981). Pannonische Ziegelstempel III: Limes-Strecke Ad Felexum-Ad Mures. Dissertationes Archaeologicae ex Instituto Archaeologico Universitatis de Rolando Eötvös nominatae 2/9. Budapest: ELTE.

Malzbender, T., Gelb, D. \& Wolters, H. (2001) Polynomial texture map. Paper presented at the annual Special Interest Group on Graphics and Interactive Techniques (SIGGRAPH) conference, Los Angeles, USA, August 12-17, 2001.

McComish, J. M. (s. a.). An Analysis of Roman Cerzmic Building Material from York and its Immediate Environs. Unpublished MA thesis. University of York.

McComish, J. M. (2015). A Guide to Ceramic Building Materials. York: York Archaeological Trust for Excavation and Research.

Mc Whirr, A. (1978). Roman Brick and Tile. Studies in Manufacture, Distribution, and Use in the Western Empire. British Archaeological Reports. International Series 68. Oxford: Archaeopress. 
Gergö István Farkas • Presenting the CLIR Database Module for Processing Roman Stamped Tiles and Ceramic...

Pósta, B. (1897). Baranya vármegye története az őskortól a honfoglalásig [The history of Baranya county from prehistoric times to the Hungarian Conquest]. In Várady, F. (ed.), Baranya múltja és jelene, vol. II (pp. 5-208). Pécs, 1897.

Rómer, F. (1866). Magyar Régészeti Krónika [A Chronicle of Hungarian Archaeology]. Archaeologiai Közlemények 6 (1866), 172, Nr. 882.

Szilágyi, J. (1933). Inscriptiones Tegularum Pannonicarum. Dissertationes Pannonicae ex Instituto Numismatico et Archaeologico Universitatis de Petro Pázmány nominatae Budapestiensis Provenientes 2/1. Budapest.

Torma, K. (1883). Római cserépedény bélyegek és karczolatok [Stamps and markings on Roman pottery]. Archaeologiai Értesítö 3 (1883), 1-72.

Visy, Zs. (2015). Corpus Limitis Imperii Romani (CLIR). In L. Vagalinski \& N. Sharankov (eds), Limes XXII: Roman Frontier Studies. Proceedings of the 22nd International Congress of Roman Frontier Studies. Ruse, Bulgaria, September 2012 (pp. 923-929). Bulletin of the National Institute of Archaeology 52. Sofia: Bulgarian Academy of Sciences, National Institute of Archaeology with Museum.

Warry, P. (2006). Tegulae: manufacture, typology and use in Roman Britain. British Archaeological Reports. British Series 417. Oxford: Archaeopress.

Wosinsky, M. (1896). Tolnavármegye története. Az öskortól a honfoglalásig [The history of Tolna county. From prehistoric times to the Hungarian Conquest]. Vols I-II, Budapest: Franklin. 